\title{
EFFECTS OF ALPHA-KETOGLUTARATE ON LIFESPAN AND FUNCTIONAL AGING OF Drosophila melanogaster FLIES
}

\author{
M. P. LYLYK ${ }^{1}$, M. M. BAYLIAK ${ }^{1}$, H. V. SHMIHEL ${ }^{1}$, \\ J. M. STOREY', K. B. STOREY', V. I. LUSHCHAK \\ ${ }^{1}$ Vasyl Stefanyk Precarpathian National University, Ivano-Frankivsk, Ukraine; \\ ${ }^{2}$ Institute of Biochemistry, Carleton University, Ottawa, Canada; \\ e-mail: lushchak@pu.if.ua; bayliak@ukr.net
}

The effects of an alpha-ketoglutarate-supplemented diet on lifespan and functional senescence were evaluated in the Canton $S$ strain of Drosophila melanogaster. The results suggest that effects of dietary alphaketoglutarate (AKG) are dose- and gender-dependent. In males, diets containing 1-10 mM AKG did not affect mean and maximum lifespans, except that an increased maximum lifespan observed at $10 \mathrm{mM} \mathrm{AKG}$. Diet with $20 \mathrm{mM}$ AKG shortened median lifespan and had no effect on maximum lifespan of males. In females, diets with low concentrations of $A K G(1$ and $5 \mathrm{mM})$ did not affect lifespan, whereas diets supplemented with 10 and $20 \mathrm{mM} A K G$ increased both median and maximum lifespans. At a lifespan-prolonging concentration (10 mM), AKG decreased fecundity, increased cold resistance and had no effect on climbing activity or resistance to oxidative stress in flies of either gender at middle (24 days) and old (40 days) ages. Moreover, middle-aged AKG-fed females but not males were more resistant to heat stress that was accompanied by higher levels of HSP90 protein as compared with controls. Middle-aged flies on AKG-supplemented diets showed elevated oxidative stress and had higher total protein and triacylglycerol levels as compared with controls. Hence, anti-aging effects of $A K G$ do not seem to be related to preventing oxidative stress development but involve metabolic rearrangement and synthesis of specific protective proteins, which aid to resist destructive processes with age.

Ke y wo rds: climbing activity, fecundity, stress resistance, oxidative stress, TCA cycle.

$\mathrm{R}$

ecent studies have demonstrated that certain normal endogenous metabolites are able to modulate aging and lifespan in a similar manner in evolutionarily diverse organisms. Alphaketoglutarate (AKG) is one of the small metabolites whose anti-aging effects are actively studied [1-5]. As an intermediate of the tricarboxylic acid (TCA) cycle, AKG is produced by oxidative decarboxylation of isocitrate catalyzed by isocitrate dehydrogenase as well as from glutamate by oxidative deamination via glutamate dehydrogenase, or as a product of various transamination reactions [3]. Some studies have shown that AKG as a dietary supplement can prevent the functional decline of many processes with age and modulate lifespan. In particular, reported potential anti-aging effects of AKG included redox state stabilization and improvement of blood vessel elasticity in aged mice [1]. Moreover, AKG supplementation was found to extend lifespan of the nematode Caenorhabditis elegans via promotion of a state similar to that induced by dietary restriction [2]. Using a fruit fly Drosophila melanogaster $w^{1118}$ line we recently found that dietary AKG prevented partially an age-dependent functional decline in flies $[4,5]$. Locomotor activity assessed by a climbing activity test and greater resistance to selected stresses were among the age-related physiological changes in flies. In particular, food supplemented with AKG prevented a decline in climbing activity and sustained resistance to temperature stress in middleaged (24 days) adult $w^{1118}$ flies compared with young flies (2-day old) [4]. In middle-aged females $w^{1118}$, dietary AKG did not affect oxidative stress parameters, but increased total protein and triacylglycerol

(C) 2018 Lylyk M. P. et al. This is an open-access article distributed under the terms of the Creative Commons Attribution License, which permits unrestricted use, distribution, and reproduction in any medium, provided the original author and source are credited. 
levels [5]. The aim of the present study was to determine if these metabolic changes and the ability of AKG to slow functional senescence in middleaged females were related to lifespan extension in D. melanogaster. Together with lifespan analysis we also evaluated a variety of metabolic, locomotor activity and stress resistance parameters as well as female fecundity in middle-aged (24 days) and old (40 days) flies in order to define physiological and behavioral characteristics affected by AKG-supplemented diets and potentially indicative of extended lifespan.

\section{Materials and Methods}

Fly stock and rearing. D. melanogaster Canton $\mathrm{S}$ flies were kindly provided by Bloomington Stock Center (Indiana University, USA). All fly cultures were kept at $25{ }^{\circ} \mathrm{C}, 55-60 \%$ humidity in a 12-h dark/ light cycle. Experimental fly cultures were reared on medium containing 5\% (w/v) sucrose, $5 \%(\mathrm{w} / \mathrm{v})$ dry yeast, $1 \%(\mathrm{w} / \mathrm{v})$ agar, $0.18 \%(\mathrm{w} / \mathrm{v})$ methylparaben to inhibit mold growth, and different concentrations $(0,1,5,10,20 \mathrm{mM})$ of the disodium salt of alphaketoglutarate (AKG).

Fecundity test. Newly eclosed flies, one male and one female, were transferred in small vials with $0.7 \mathrm{ml}$ of the same food as they fed at egg and larval stages. Food was changed every other day. The number of eggs laid by individual female (in one vial) was counted at $24 \mathrm{~h}$ after transfer onto fresh food [6]. Measurements were performed during the first 22 days of adult life. Eggs were counted every second day. Eighteen fly pairs were tested for each control and AKG group.

Lifespan assay. Newly eclosed flies were transferred onto fresh food of the same composition and held for 2 days. Then, flies were separated by sex under light $\mathrm{CO}_{2}$ anesthesia and approximately 80100 flies of each sex were placed in the demographic cage with volume of 1.51 . A plastic vial filled with $5 \mathrm{ml}$ of food (control or experimental) was attached to the cage. The food was changed every second day. Three independent trials with about 80-100 flies per diet and sex were performed. Maximum lifespan was defined as the mean lifespan of the last 10\% survivors.

Climbing activity and stress resistance assays. Flies were separated by sex under $\mathrm{CO}_{2}$ anesthesia and transferred to empty vials to recover (120 min). After this, flies were used for various physiological tests. To induce a climbing response, flies were gen- tly tapped to the bottom of the vial and given $20 \mathrm{sec}$ to climb $5 \mathrm{~cm}$ upwards [6]. After this, the number of the flies that climbed a distance of $>5 \mathrm{~cm}$ was counted and expressed as a percentage. Flies in each vial were tested three times and means were calculated. Cold tolerance was estimated as the time required for recovery from chill coma [7]. Vials containing 8-10 adult flies ( $24 \mathrm{~d}$ old $)$ were put in a water bath with melting ice $\left(0^{\circ} \mathrm{C}\right)$ for $2 \mathrm{~h}$. Flies were then transferred into Petri dishes at ambient laboratory temperature $\left(25^{\circ} \mathrm{C}\right)$ and chill coma recovery time was monitored. A fly was considered as having recovered from chill coma when it was able to stand on its legs. To evaluate resistance to heat stress, single flies were transferred into small glass vials with cotton stoppers and placed in water baths set at $40^{\circ} \mathrm{C}$. Full immobility of the fly was referred to as heat-induced paralysis, and the time taken to reach coma was recorded [8]. To measure starvation resistance, groups of 10 flies $(24 \mathrm{~d}$ old $)$ were transferred to $24 \mathrm{ml}$ glass vials containing $1.25 \mathrm{ml}$ of $1 \%$ agar and plugged with cotton in order to prevent desiccation. Dead fly number was recorded every $24 \mathrm{~h}$. For the oxidative stress assay, 10 flies were transferred into vials containing folded strips of cellulose filter paper soaked with $0.8 \mathrm{ml}$ of $5 \%(\mathrm{w} / \mathrm{v})$ sucrose solution containing $5 \%(\mathrm{w} / \mathrm{v}) \mathrm{H}_{2} \mathrm{O}_{2}$. Survivors were counted at defined time intervals over $48 \mathrm{~h}$ of exposure. In starvation and oxidative stress tests, data were expressed as the percentage of flies that survived.

Preparation of homogenates of flies for metabolite analyses. Flies from groups that were to be processed for subsequent biochemical analyses were flash frozen in liquid nitrogen and then stored frozen at $-65{ }^{\circ} \mathrm{C}$ until use. Frozen flies were weighed and homogenized in lysis buffer $(50 \mathrm{mM}$ potassium phosphate buffer ( $\mathrm{pH}$ 7.0), $1 \mathrm{mM}$ phenylmethylsulphonyl fluoride, $0.5 \mathrm{mM}$ EDTA) at $1: 10$ ratio (w/v). After centrifugation at $16,000 \mathrm{~g}$ for $15 \mathrm{~min}$ at $4{ }^{\circ} \mathrm{C}$ in an Eppendorf 5415 R centrifuge (Hamburg, Germany), the supernatants were collected and used for different assays and protein determination with spectrophotometers Spekol 211 (Carl Zeiss Jena, Jena, Germany) and SF-46 (LOMO, USSR). Supernatants were kept on ice.

Assays of catalase activity and soluble protein concentration. The activity of catalase (EC 1.11.1.6) was measured by monitoring disappearance of hydrogen peroxide at $240 \mathrm{~nm}$ using the extinction coefficient for $\mathrm{H}_{2} \mathrm{O}_{2}$ of $39.4 \mathrm{M}^{-1} \mathrm{~cm}^{-1}$ [9]. One unit of catalase activity was defined as the amount of the 
enzyme consuming $1 \mu \mathrm{mol}$ of $\mathrm{H}_{2} \mathrm{O}_{2}$ per minute; the activity was expressed as international units per milligram of the soluble protein ( $\mathrm{U}$ mg protein ${ }^{-1}$ ). Soluble protein concentration was determined by the Coomassie brilliant blue G-250 dye-binding method [10].

Assays of protein thiols, low-molecular mass thiols, and lipid peroxide levels. Free thiols were measured spectrophotometrically by the Ellman procedure with 5,5'-dithiobis-2-nitrobenzoic acid (DTNB) at $412 \mathrm{~nm}$ [11]. Briefly, the sum of soluble low molecular mass and high molecular mass (protein) thiols was measured in the supernatants. To determine the nonprotein low-molecular mass thiols (L-SH), trichloroacetic acid was added to supernatants to a final concentration of $10 \%$ followed by centrifugation $\left(10,000 \mathrm{~g}\right.$ for $15 \mathrm{~min}$ at $\left.21^{\circ} \mathrm{C}\right)$ to precipitate protein. The supernatants were then used to assay L-SH. Absorption was read at $412 \mathrm{~nm}$ and a molar extinction coefficient for thiol conjugates with DTNB of $14 \times 10^{3} \mathrm{M}^{-1} \mathrm{~cm}^{-1}$ was used to calculate thiol levels. Protein thiol content was calculated by subtraction of the amount of low-molecular mass thiols from the total values. Thiol concentrations were expressed as micromoles of $\mathrm{SH}$-groups per gram of wet mass. Lipid peroxide ( $\mathrm{LOOH})$ content was assayed with xylenol orange [12]. For this, flies were homogenized $1: 20(\mathrm{w} / \mathrm{v})$ in $96 \%$ cold $\left(\sim 5^{\circ} \mathrm{C}\right)$ ethanol, centrifuged for $5 \mathrm{~min}$ at $16,000 \mathrm{~g}$ at $4{ }^{\circ} \mathrm{C}$ and supernatants were used for assay. The content of LOOH was expressed as nanomoles of cumene hydroperoxide equivalents per gram of wet mass.

Assays of glucose and triacylglycerol concentrations. Glucose levels were measured using a diagnostic kit Liquick Cor-GLUCOSE (PZ Cormay S.A., Łomianki, Poland) following the manufacturer's instructions. For assay, aliquots of supernatants prepared as above for metabolite analysis were heated at $70{ }^{\circ} \mathrm{C}$ for $5 \mathrm{~min}$ to denature protein followed by centrifugation to precipitate protein. Supernatants were saved and used for measurement of glucose levels. Standard glucose solutions in a concentration range from 2 to $20 \mu \mathrm{g} \mathrm{ml}^{-1}$ were used to build a calibration curve. For triacylglycerol assay, pre-weighed flies were homogenized in chilled $10 \mathrm{mM}$ PBST buffer (phosphate buffered saline containing $0.05 \%$ Triton X100) in a ratio $1: 50$ (mg flies : $\mu$ l buffer). Homogenates were heated for $10 \mathrm{~min}$ at $70{ }^{\circ} \mathrm{C}$ to denature proteins. Triacylglycerol (TAG) levels were measured using a diagnostic kit Liquick Cor-TG (PZ Cormay S.A., Łomianki, Poland) following the manufacturer's instructions. Standard TAG solutions in the concentration range from 3 to $30 \mu \mathrm{g} \mathrm{ml}^{-1}$ were used for calculation of TAG content in flies. The levels of glucose and TAG were expressed as milligrams per gram of wet mass.

Determination of total free amino acid and proline levels. To determine levels of free amino acids and proline, proteins in fly extracts were precipitated with 10\% trichloroacetic acid (final concentration) followed by centrifugation for $5 \mathrm{~min}$ at 13,000 g at room temperature. Free proline levels were measured according to the procedure of Bergman and Loxley [13] based on reaction of proline with ninhydrin forming red pigment with absorbance peak at $512 \mathrm{~nm}$. Proline solutions containing from 2 to $100 \mathrm{nmol}$ were used for the calibration curve. The proline concentrations were expressed as micromoles per gram of wet mass. Total free amino acid concentrations in fly extracts were determined by reaction with ninhydrin with absorbance of formed complex measured at $570 \mathrm{~nm}$ [14]. Glutamic acid in a range from 2 to $80 \mathrm{nmol}$ was used for the calibration curve. The total pool of amino acids was expressed as micromoles of glutamic acid equivalents per gram of wet mass.

SDS-PAGE and western blotting. Twenty frozen flies were homogenized on ice at 1:20 ratio $(\mathrm{w} / \mathrm{v})$ in a cold RIPA buffer (\# R0278, Sigma-Aldrich) containing $480 \mathrm{mg}$ urea $(8 \mathrm{M}), 50 \mathrm{mg}$ sodium dodecyl sulfate (SDS) (5\%), and $50 \mu \mathrm{l}$ of protease inhibitor solution (Carl Roth GmbH + Co. KG (Karlsruhe, Germany), \#3743.1) in a final volume of $1 \mathrm{ml}$. After centrifugation at $16,000 \mathrm{~g}$ for $15 \mathrm{~min}$ at $4{ }^{\circ} \mathrm{C}$, the supernatants were collected and used for soluble protein determination and western blot procedure. Protein concentration was determined by Bradford assay [10]. For western blotting, supernatants were mixed with Laemmli buffer (Sigma-Aldrich, \#S3401) at ratio of $6: 1(\mu \mathrm{l} / \mu \mathrm{l})$ and heated for $5 \mathrm{~min}$ at $90^{\circ} \mathrm{C}$ to denature protein. Denaturing polyacrylamide gel electrophoresis (SDS-PAGE) was performed on $7.5 \%$ stacking and $10 \%$ separating gels in standard Tris-glycine buffer ( $\mathrm{pH}$ 8.3). Equal quantities of samples containing $20 \mu \mathrm{g}$ of total protein were loaded onto separate SDS-PAGE lanes. PagerRuller plus prestained protein ladder (ThermoFisher Scientific, \#26619, $3 \mu 1$ /lane) was loaded into the first lane to verify electrotransfer of proteins. Electrophoresis was performed at $100 \mathrm{~V}$ through the stacking gel for about $30 \mathrm{~min}$ and $180 \mathrm{~V}$ through the separating gel for $2 \mathrm{~h}$. Proteins fractionated by SDS-PAGE were electroblotted onto nitrocellulose membrane 
(ThermoFisher Scientific, \#IB4010-01). The efficiency of transfer and equality of proteins in each lane was carefully monitored by Ponceau-S (Sigma-Aldrich, \#P3504) staining. The membrane was blocked with $5 \%(\mathrm{w} / \mathrm{v})$ non-fat dried milk in PBS (phosphate-buffered saline) buffer containing 0.05\% (v/v) Tween-20 (Sigma-Aldrich, \#P1379) for $1 \mathrm{~h}$ with gentle shaking at room temperature. Primary antibodies were diluted 1:1,000 in PBS-0.1\% Tween-20 containing $0.5 \%$ dried milk. The blots were incubated with diluted rabbit polyclonal anti-HSP90 (Cell Signaling Technology, \#4874S) overnight at $4{ }^{\circ} \mathrm{C}$ with gentle shaking and then washed three times in PBS- $0.1 \%$ Tween-20. The blots were further incubated in anti-rabbit-IgG-HRP-linked antibody diluted (Cell Signaling Technology, \#7074S, 1:2,500 dilution) for $1 \mathrm{~h}$ with shaking at room temperature followed by three times washing in PBS- $0.1 \%$ Tween-20. The cross-reacting protein band signals were detected using Pierce ECL Western Blotting Substrate (ThermoFisher Scientific, \#32209). After staining, the blots were scanned immediately, and the intensities of the reactive protein bands were measured in arbitrary units using TotalLab Quant Software.

Statistical analysis. Lifespan and stress resistance curves were analyzed by the Log rank test using R Project (R version 3.2.4 software). A two-tailed Student's $t$-test and analysis of variance (ANOVA) followed by a two-tailed Dunnett's test were used for statistical analysis of fecundity and maximum lifespan, respectively. The rest of the data (column graphs) were analyzed by two-way or three- way ANOVA (Origin 8.5 SR1 software) when two or three factors, respectively, were varied: diet (control food vs. AKG-supplemented food), gender (males $\mathrm{v}$ vs. females), and age (24-day old flies vs.40-day old ones). Experimental data are expressed as the mean value \pm standard error of the mean (SEM) and $P$ value $\leq 0.05$ was considered as significant.

\section{Results and Discussion}

Alpha-ketoglutarate supplementation modulates D. melanogaster lifespan in concentration- and gender-dependent manners. Previously, AKG was found to increase lifespan in nematodes (C. elegans) in a concentration-dependent way, with $8 \mathrm{mM}$ AKG promoting maximum lifespan extension [2]. In this study, we examined the ability of dietary AKG to prolong lifespan of D. melanogaster flies. For this aim, wild-type Canton $\mathrm{S}$ males and females were cultured starting from the egg stage on standard food (5\% yeast / 5\% sucrose) supplemented with $0,1,5,10$ or $20 \mathrm{mM}$ AKG. Males and females had similar lifespans when were fed control food (Fig. 1). Mean and maximal lifespans of males were not affected by food containing 1 or $5 \mathrm{mM}$ AKG (Fig. 1, A and Table 1). Consumption of food supplemented with $10 \mathrm{mM}$ AKG extended the maximum lifespan of males by $11 \%$, without affecting mean lifespan, compared to controls (Fig. 1, $A$ and Table 1). Food supplementation with $20 \mathrm{mM}$ AKG promoted shorter lifespan and higher age-dependent mortality in males compared to the control group ( $P<0.001$, log-rank test), indicating possible toxic effects of $A K G$ at the higher concentrations
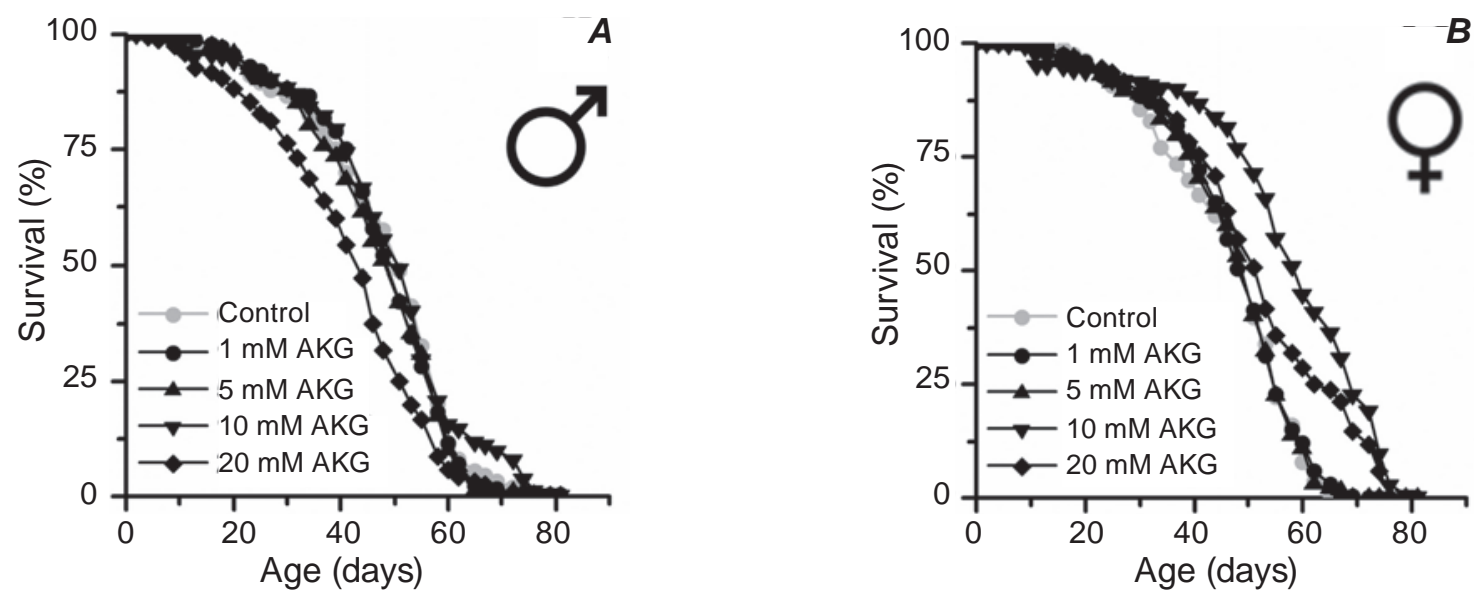

Fig. 1. Survival of male (A) and female (B) Canton $S$ flies fed diets with different AKG concentrations. The difference between lifespans was analyzed by a log-rank test with 200-300 flies in each group. For more information see Table 1 
(Fig. 1, A). As a result, males fed with $20 \mathrm{mM} \mathrm{AKG}$ had a $13.7 \%$ shorter mean lifespan but unchanged maximum lifespan, compared to controls (Table 1). In females, lower concentrations of AKG (1 and $5 \mathrm{mM}$ ) did not affect lifespan (Fig. 1, B). Significant differences were found between lifespans of control females and females fed with 10 and $20 \mathrm{mM} \mathrm{AKG}$ $(P<0.001$, log-rank test). Accordingly, females had 23 and 11\% longer mean lifespan and 22 and 19\% longer maximum lifespan on food supplemented with 10 and $20 \mathrm{mM}$ AKG, respectively, compared to controls (Table 1). Thus, AKG changed both mean and maximum lifespan in D. melanogaster Canton $\mathrm{S}$ in a concentration-dependent manner, being particularly effective at $10 \mathrm{mM} \mathrm{AKG}$ and with a substantially greater effect on female flies. Opposite effects of $20 \mathrm{mM} \mathrm{AKG}$ on lifespan of Canton S males and females suggest that high concentrations of AKG are more toxic for male flies than for female ones.

Alpha-ketoglutarate does not confer stress resistance in old flies and reduces fecundity. Decline in locomotor activity and stress resistance are the most studied age-related changes in D. melanogaster $[6,8,15]$. To evaluate the ability of dietary AKG to modulate functional senescence, we measured locomotor activity and resistance to several stresses in middle-aged (24 days) and old (40 days) flies maintained on control food versus food containing $10 \mathrm{mM}$ AKG. This concentration of AKG was cho- sen because it had the greatest lifespan-promoting effect in the prior experiments.

Locomotor function was measured by using a climbing assay based on negative geotaxis behavior [15]. Climbing activity was not affected by diet and gender but depended on age of flies (Fig. 2, A). Expectably, middle-aged flies of both genders had higher climbing activity than respective old ones (Fig. 2, A). Values of climbing activity of flies fed food supplemented with $10 \mathrm{mM}$ AKG were not significantly different from the corresponding control group for either sex. Hence, AKG did not improve locomotor behavior in either middle-aged or old flies. These results are not fully consistent with our previous study using the $w^{1118}$ strain in which dietary AKG improved the climbing activity of both males and females in middle-aged groups [4].

To compare stress resistance of flies fed control and AKG-supplemented food, we examined sensitivity of middle-aged and old flies to $\mathrm{H}_{2} \mathrm{O}_{2}$-induced oxidative stress, starvation, and temperature stress. Maintenance on the food with AKG did not affect resistance to $\mathrm{H}_{2} \mathrm{O}_{2}$ by flies in either age group (Fig. 2, $B$ ). Middle-aged ( $24 \mathrm{~d}$ old) males but not females from both control and experimental groups were more sensitive to hydrogen peroxide than respective 40-day old ones. Independent of food type and age, females were more resistant to hydrogen peroxide than males with a high percentage of females (about

\section{Ta ble 1. Lifespan trials of control flies and flies fed food supplemented with AKG}

\begin{tabular}{c|c|c|c|c}
\hline Total no. of flies & $\begin{array}{c}\text { AKG concentration } \\
(\mathrm{mM})\end{array}$ & $\begin{array}{c}\text { Mean lifespan } \\
\text { (days) (\%change) }\end{array}$ & $\begin{array}{c}\text { Log-rank } \\
\text { (vs control) }\end{array}$ & $\begin{array}{c}\text { Maximum } \\
\text { lifespan (days) }\end{array}$ \\
\hline \multicolumn{5}{|c}{ Males } \\
391 & 0 (control) & $47.9 \pm 0.7$ & $63.1 \pm 0.6$ \\
252 & 1 & $47.8 \pm 0.8(0)$ & $P=0.161$ & $62.6 \pm 0.7$ \\
242 & 5 & $47.1 \pm 0.9(-1.7)$ & $P=0.190$ & $62.9 \pm 0.9$ \\
330 & 10 & $49.2 \pm 0.8(+2.8)$ & $P=0.121$ & $69.9 \pm 0.5^{*}$ \\
338 & 20 & $41.4 \pm 0.9(-13.6)$ & $P<0.001$ & $61.7 \pm 0.7$ \\
& & Females & \\
234 & $0($ control) & $46.4 \pm 0.8$ & $61.1 \pm 0.6$ \\
316 & 1 & $47.2 \pm 0.7(+1.7)$ & $P=0.190$ & $61.5 \pm 0.5$ \\
265 & 5 & $47.0 \pm 0.8(+1.3)$ & $P=0.640$ & $61.7 \pm 0.6$ \\
331 & 10 & $57.1 \pm 1.0(+23.0)$ & $P<0.001$ & $74.8 \pm 0.4^{*}$ \\
\hline
\end{tabular}

Maximum lifespan was defined as the mean lifespan of the last $10 \%$ survivors. *Significantly different $(P<0.01)$ from the control group as evaluated by one-way ANOVA with Dunnett's test 

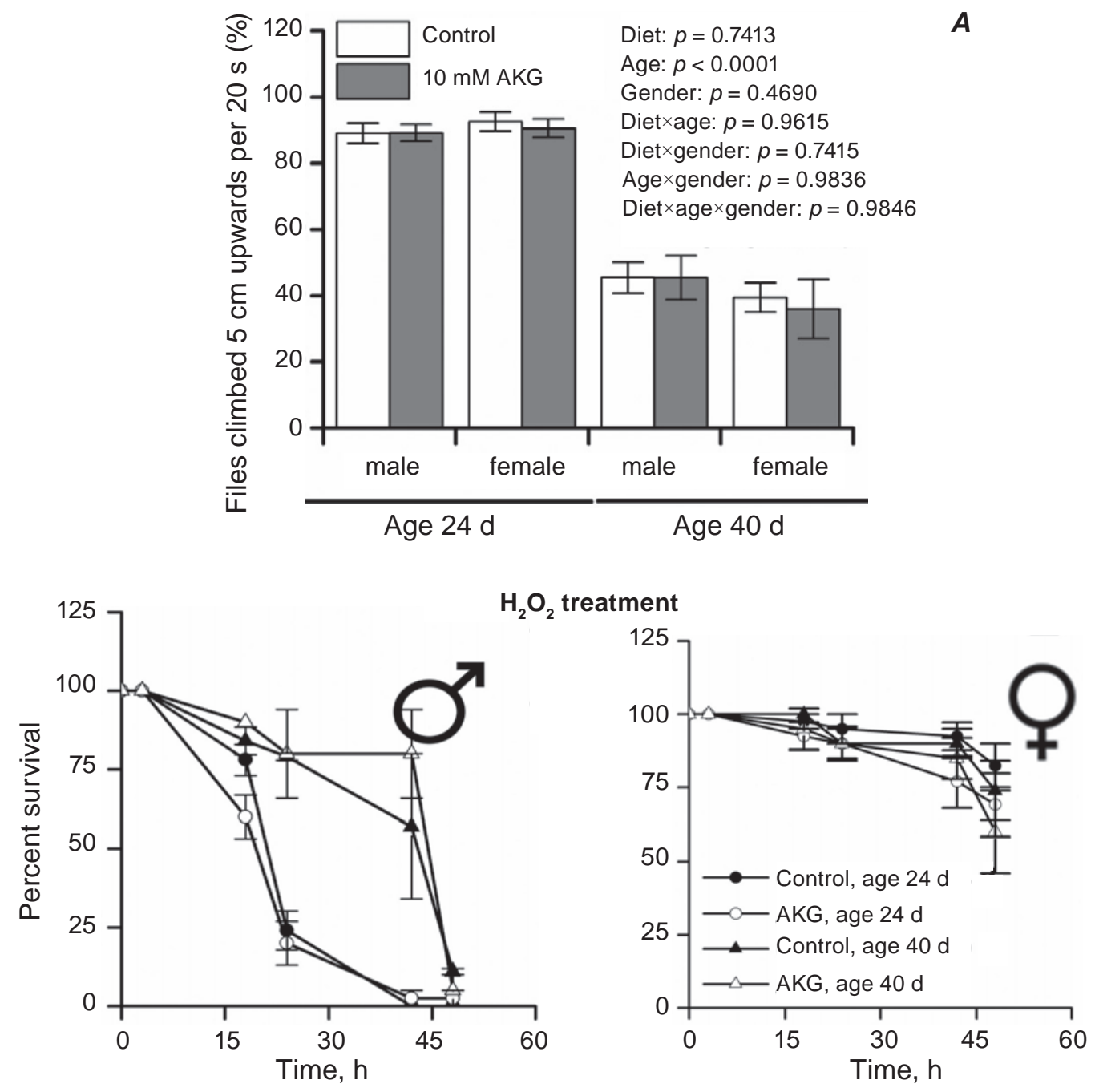

Fig. 2. Climbing activity and oxidative stress resistance of 24-day and 40-day old Canton S flies fed control food or food supplemented with $10 \mathrm{mM} \mathrm{AKG.} \mathrm{(A)} \mathrm{Climbing} \mathrm{activity} \mathrm{was} \mathrm{measured} \mathrm{as} \mathrm{the} \mathrm{percentage} \mathrm{of} \mathrm{flies}$ that climbed $5 \mathrm{~cm}$ upwards in 20 seconds. Data are means \pm SEM of three independent experiments with 3040 flies per gender and are analyzed by three-way ANOVA. (B) Effects of $5 \% \mathrm{H}_{2} \mathrm{O}_{2}$ on the survival of flies. Data are means $\pm S E M$ of three independent experiments with 20 flies per replicate

$60-80 \%)$ still alive after $48 \mathrm{~h}$ whereas less than $10 \%$ of males were alive. Similar sex-specific differences in oxidative stress resistance in relation to longevity have been reported recently [16]. Previously, we did not find any effects of dietary AKG on oxidative stress resistance in 24-day old $w^{1118}$ females and the same was true here. Diet supplemented with AKG conferred resistance to hydrogen peroxide only in young (2-day old) flies [5].

Resistance to heat stress was evaluated in flies by measuring time taken to reach heat coma. Heat coma onset depended on age and gender but not on diet individually. We also found the interaction between diet and age was on heat stress resistance (Fig. 3, A). Diet with AKG increased heat stress re- sistance in 24-day old flies only but did not confer the resistance in 40-day old ones. Independent of diet, middle-aged flies were more resistant to heat stress than 40-day old ones. The obtained results are consistent with higher heat stress resistance observed previously for 24-day old AKG-fed $w^{1118}$ females compared with control ones [5]. It should be noted that feeding with AKG-containing diet increased the HSP90 protein content in unstressed females determined by immunoblotting, but did not affect HSP90 level in males as compared with controls (Fig. 3, B). Since the importance of HSP90 function to the heat shock response in $D$. melanogaster has been clearly documented [17], higher level of HSP90 protein in AKG-fed females could contribute to the higher heat 


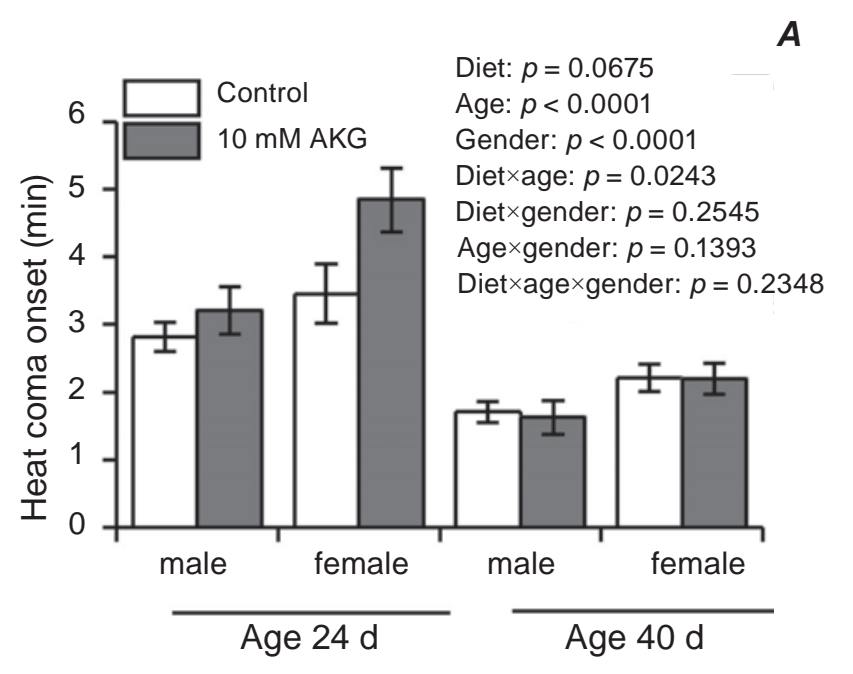

B

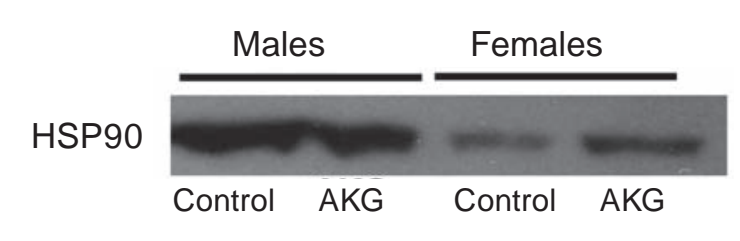

C
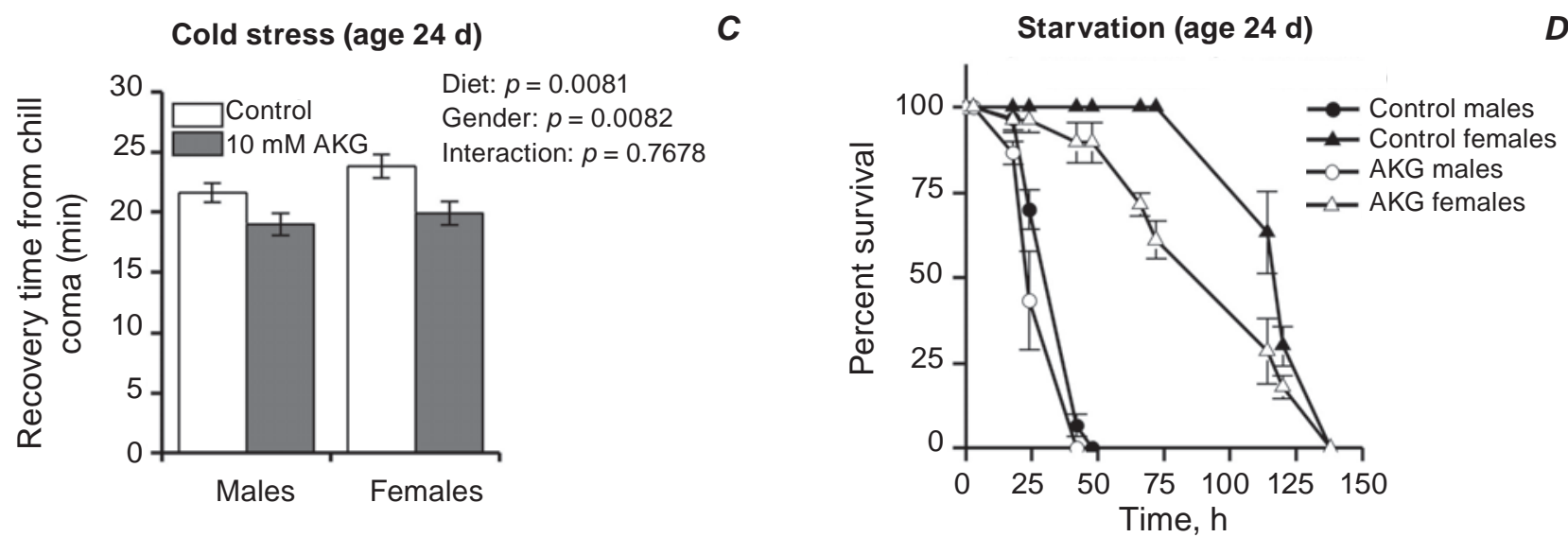

Fig. 3. Stress resistance of 24-day and 40-day old Canton $S$ flies fed control food or food supplemented with $10 \mathrm{mM}$ AKG. (A) Time of onset of thermally-induced coma at $40^{\circ} \mathrm{C}$. Data are means $\pm S E M$ of three independent experiments with 10-12 flies of each gender per replicate and are analyzed by three-way ANOVA. (B) Western blot of HSP90 protein from bodies of 24-day old flies. Samples of $20 \mu \mathrm{g}$ of total protein were applied in each lane. Data are from a representative experiment (C) Recovery time from chill coma in 24-day old flies. Data are means \pm SEM of three separate experiments with 10-20 flies per gender and are analyzed by two-way ANOVA. (D) Survival during starvation. Data are means \pm SEM of three independent experiments with 10 flies per replicate. The difference between survival curves was analyzed by a log-rank test

stress tolerance of these flies compared with control ones. In support of this, AKG was found recently to increase levels of heat shock proteins (HSP70 and HSP90) in fish [18].

To assess cold tolerance, the recovery from chill coma was monitored for 24-day old flies. Cold tolerance depended on both diet and gender (Fig. 3, $C)$. Independent on diet type, females were more resistant to cold treatment than males. Both 24-day old males and females fed on food supplemented with AKG recovered from chill coma faster (by 12\% and $16 \%$, respectively) than control ones. Thus, AKGsupplemented diet increased resistance to cold stress in middle-aged flies that is line with our previous data on young Canton S flies [7] and middle-aged $w^{1118}$ flies [5].

The diet with AKG did not enhance resistance to starvation for either 24-day old males or females and, indeed, AKG-fed females were actually more sensitive to starvation than controls (Fig. 3, D). However, independent of diet type, males were much more sensitive to starvation than females with males surviving no more than 2 days of starvation whereas about $25 \%$ of females were still alive after 5 days.

In Drosophila, lifespan is often inversely correlated with fecundity $[8,19]$. On the other hand, drugs that achieve longevity benefits by reducing fecundity were proposed as probably not useful for the even- 
tual treatment of aging [6]. We showed previously that food supplemented with AKG significantly decreased fecundity of $w^{1118}$ females [5]. Here, we observed similar results for Canton $\mathrm{S}$ females, which had lower average fecundity on food containing $10 \mathrm{mM}$ AKG, compared to controls at most ages, ranging from 6 to 16 days old (Fig. 4).

Thus, food supplemented with AKG decreased fecundity in females and increased tolerance to cold treatment in both genders. However, dietary AKG did not improve locomotor activity or resistance to starvation, oxidative or heat stresses in middleaged and old Canton S flies of both genders, except that middle-aged females showed higher heat stress resistance than controls. Since we demonstrated an earlier a positive impact of AKG on locomotor activity, oxidative and temperature (cold and heat) stresses in middle-aged $w^{1118}$ flies [4, 5], the results of the present study surmise that effects of AKG on functional senescence in Drosophila can be strainspecific.

Relationship between effects of AKG on physiological traits and levels of some metabolites in 24day old flies. To test if physiological effects of AKG were connected with changes in metabolic processes, we measured certain biochemical parameters in 24-day old Canton $\mathrm{S}$ flies reared on control food and food containing $10 \mathrm{mM} \mathrm{AKG}$.

Protective proteins and low molecular mass compounds with cryoprotective properties, such as amino acids (proline) and carbohydrates (glucose and trehalose) are important components of insect cold resistance [7, 20]. Earlier, we showed that dietary AKG increased cold tolerance in young Canton $\mathrm{S}$ and $w^{1118}$ flies reared on AKG supplemented diet; cold tolerance correlated with higher levels of soluble protein and free amino acids, in particular proline $[5,7]$. In middle-aged $w^{1118}$ flies, AKG-promoted cold resistance was accompanied with higher levels of protein, free amino acids, and glucose in females only but not in males [4]. In this study, we found that levels of total free amino acids (Fig. 5, A) and proline (Fig. 5, B) were not affected by diet and gender, whereas glucose level (Fig. 5, C) and soluble protein (Fig. 5, D) depended on diet type. Additionally, protein level depended on gender of flies (Fig. 5, D). Thus, diet supplemented with $10 \mathrm{mM}$ AKG promoted 35\% and 22\% higher total glucose levels (Fig. 5, C), and 19\% and 38\% higher soluble protein levels (Fig. 5, D) in middle-aged males and females, respectively, compared to control flies. Be-

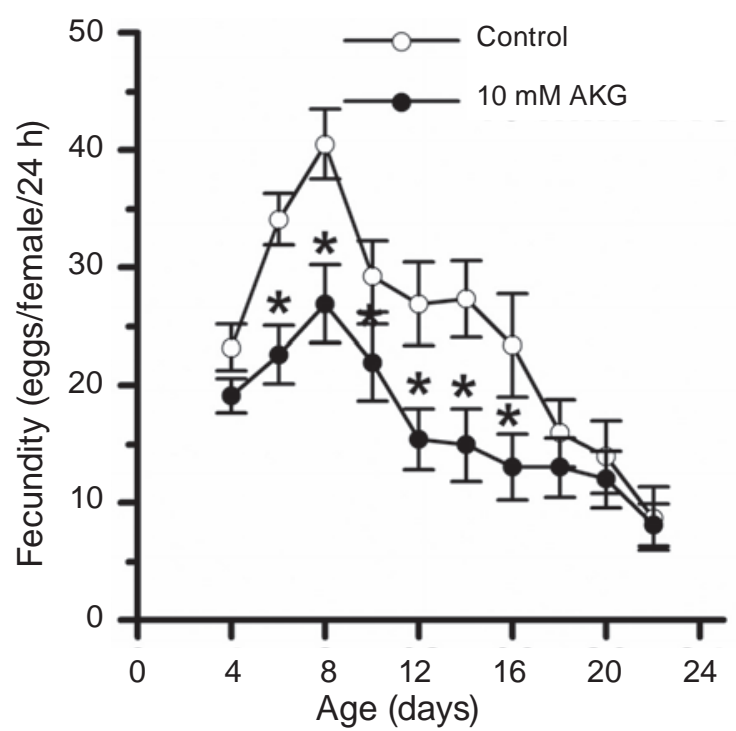

Fig. 4. Fecundity of Canton $S$ females fed with control food or food supplemented with $10 \mathrm{mM} \mathrm{AKG}$ at different ages. Data are means \pm SEM for values obtained from 18 females per group. *Significantly different $(P<0.05)$ from the corresponding value in control group by Student's $t$-test

sides low-molecular mass cryoprotective molecules, an increased level of total proteins was found to be protective in cold-selected lines of $D$. melanogaster [20]. Therefore, we propose that the higher total soluble protein levels in AKG-reared Canton S flies may also be contributing to their increased cold tolerance.

In addition to higher protein levels, females fed with AKG possessed 49\% higher TAG levels (Table 2) compared to the controls. Higher levels of protein and TAG in middle-aged females can be also connected with lower fecundity of flies on the AKGsupplemented diet (Fig. 4). Egg production requires both protein synthesis and energy expenditure. Therefore, it can be supposed, that control females spent more protein and energy for egg laying and as a result they accumulated fewer fuel reserves, such as TAG, as compared with AKG-fed flies. Body lipid content often correlates with starvation resistance in insects [21]. In our case, higher TAG levels (Table 1) did not confer resistance of AKG-fed flies to starvation (Fig. 3, B). Similar results were demonstrated by Hoffmann et al. [22] who observed no correlation between starvation resistance and body lipid content in D. melanogaster females from different populations. On the other hand, increased lipid stores were shown to be one of characteristics of long-lived lines of flies [6]. 
$A$

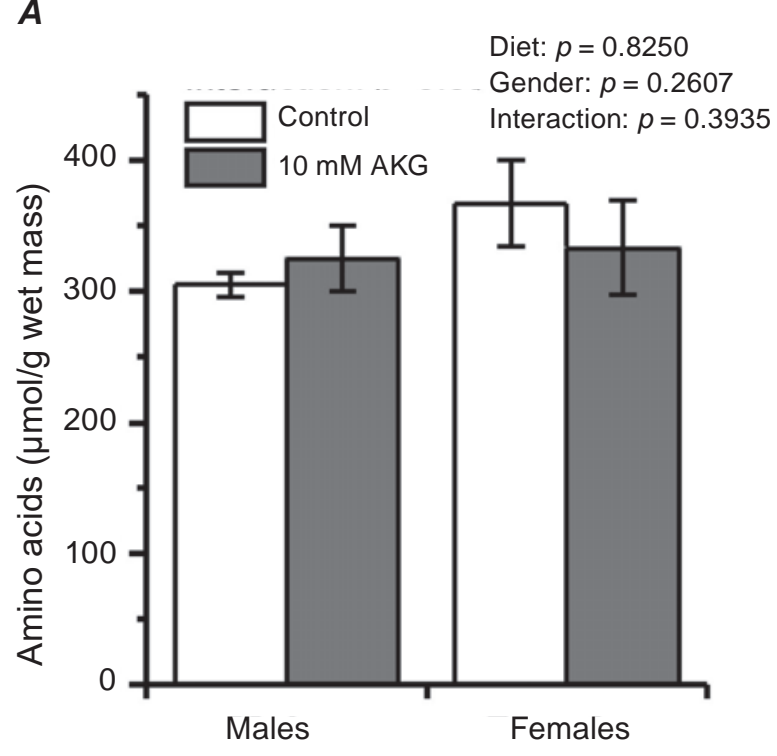

C

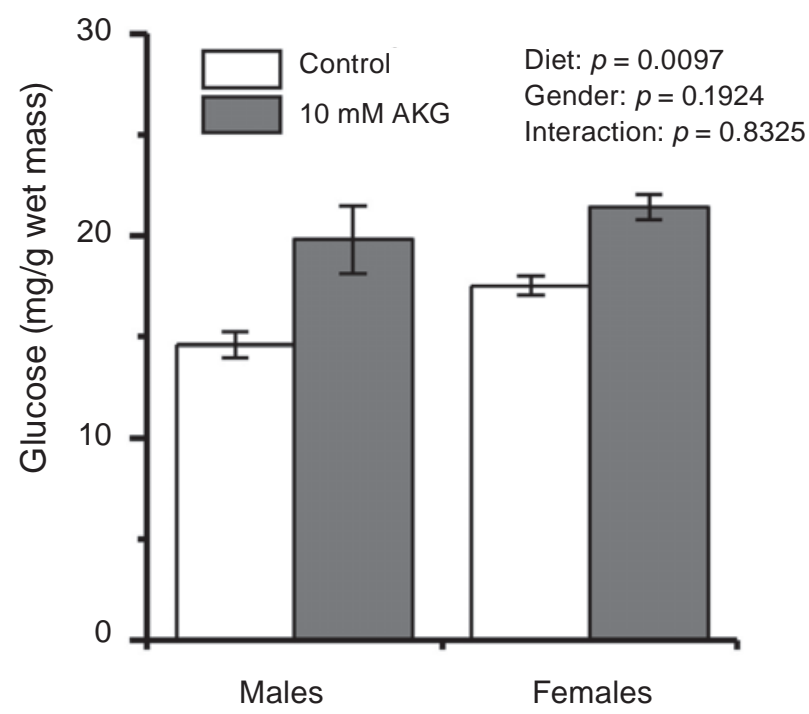

B

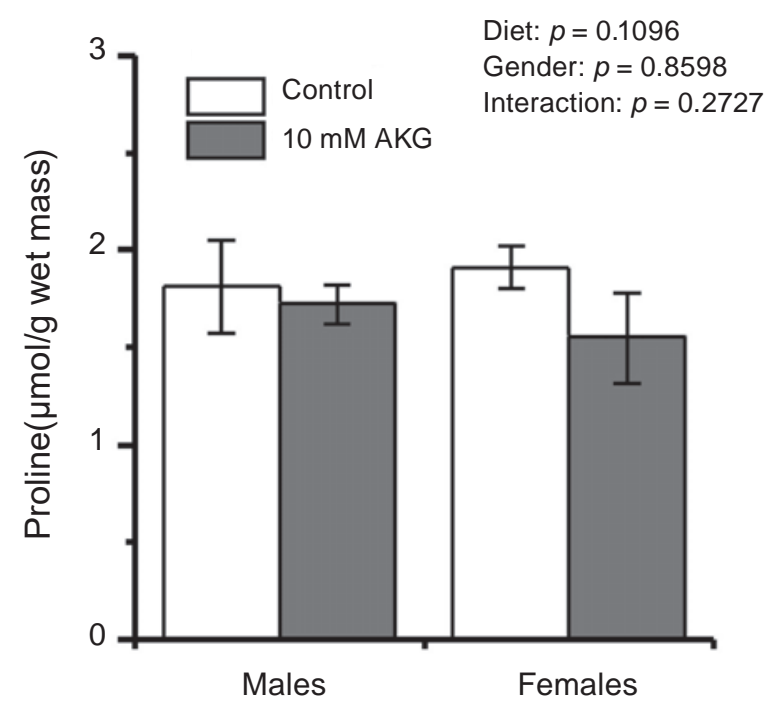

D

Diet: $p=0.0067$

Gender: $p=0.0115$

Interaction: $p=0.1852$

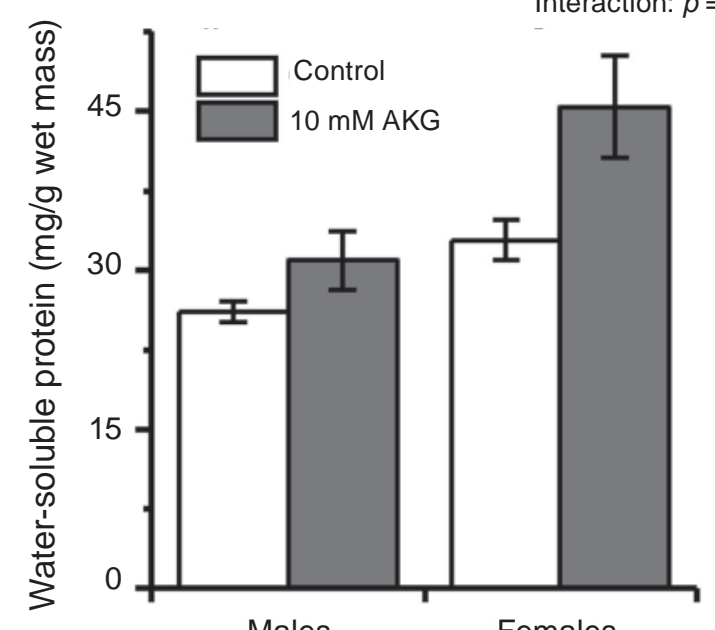

Fig. 5. Levels of free amino acids (A), proline (B), glucose (C), and water-soluble protein (D) in whole bodies of 24-day old male or female Canton Sflies fed control food or food supplemented with $10 \mathrm{mM} \mathrm{AKG.} \mathrm{Data} \mathrm{are}$ means $\pm S E M, n=4-8$. Statistical analysis was performed by using two-way ANOVA

Ta b le 2. Levels of triacylglycerols and lipid peroxides in 24-day old Canton S females fed control food or food supplemented with $10 \mathrm{mM} \mathrm{AKG}$

\begin{tabular}{l|c|c}
\hline \multirow{2}{*}{ Parameter } & \multicolumn{2}{|c}{ Conditions } \\
\cline { 2 - 3 } & Control & $10 \mathrm{mM} \mathrm{AKG}$ \\
\hline Triacylglycerols (mg/g wet mass) & $25.4 \pm 2.7$ & $37.8 \pm 2.6^{*}$ \\
Lipid peroxides (nmol cumene equivalents/g wet mass) & $963 \pm 62$ & $1372 \pm 104^{*}$ \\
\hline
\end{tabular}

Data are means \pm SEM, $n=4-6$. *Significantly different $(P<0.05)$ from control group by Student's $t$-test 
$A$

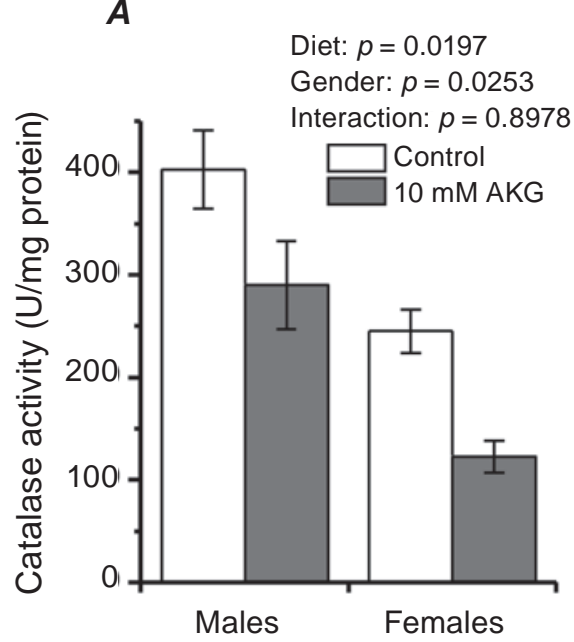

B

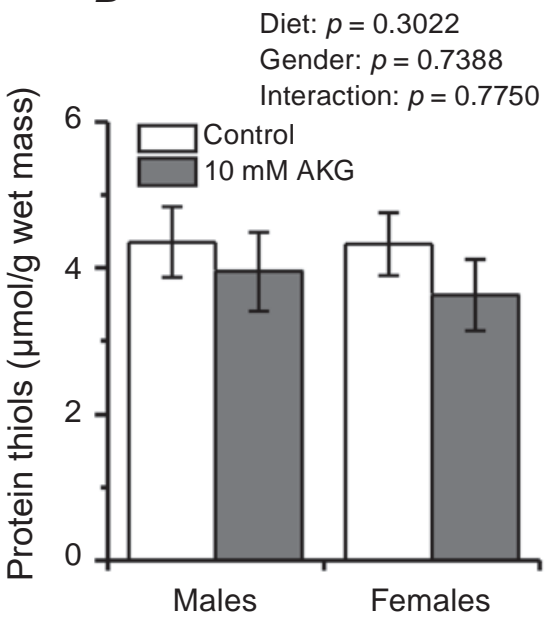

$c$

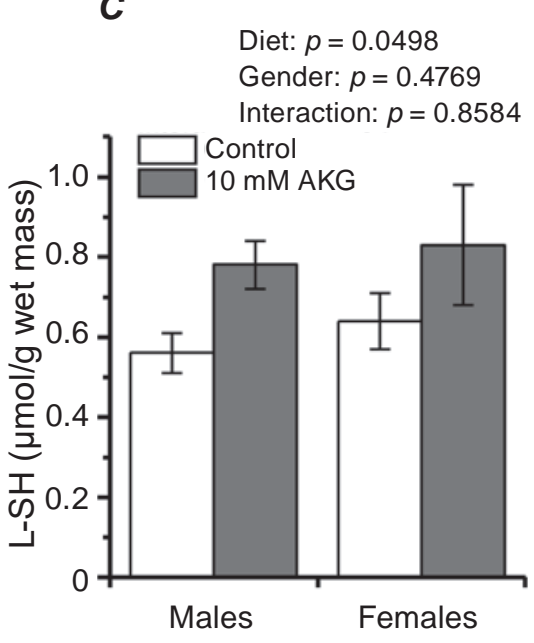

Fig. 6. Selected characteristics of antioxidant defense in 24-day old Canton Sflies fed control food or food supplemented with $10 \mathrm{mM}$ AKG: (A) catalase activity, (B) levels of protein thiols, and (C) levels of low-molecular mass thiols. Data are means $\pm S E M, n=4-8$. Statistical analysis was performed by using two-way ANOVA

Alpha-ketoglutarate induces oxidative stress in 24-day old flies. Previously, it was found that AKG modulated redox homeostasis in aged mice [1]. However, in our study with D. melanogaster $w^{1118}$ females, a positive effect of AKG on antioxidant status of middle-aged flies did not occur [5]. Here, we decided to explore the influence of AKG on the antioxidant system of 24-day old Canton S flies. For this aim, the activity of catalase, a major antioxidant enzyme, and levels of oxidative stress markers, namely thiol-containing compounds and lipid peroxides, were measured. Independent of gender, diet type affected calalase activity and levels of low molecular mass thiols (L-SH) (Fig. 6, $A$ and $C$ ) but had no influence on protein thiol levels (Fig. 6, $B$ ). Middle-aged males and females fed AKG-containing diet showed lower catalase activity by 28 and $50 \%$, respectively (Fig. 6, $A$ ), and 38 and 29\% higher L-SH levels (Fig. 6, C), compared to control flies. In addition, AKG-fed females had a 42\% higher level of lipid peroxides than controls indicating a possible increase in ROS-induced lipid peroxidation (Table 2).

The results suggest that AKG promoted development of oxidative stress in middle-aged Canton S flies of both genders. Previous studies showed that AKG can lead to an increase in production of reactive oxygen species (ROS) via changes in mitochondrial metabolism $[2,23]$. Increased ROS levels, in turn, can promote an increase in oxidation of biomolecules and/or activation of antioxidant defenses. Our results give some support to this idea because of the increased levels of lipid peroxides (a marker of oxidative stress) and levels of low molecular mass thiol antioxidants found in AKG-fed flies. Glutathione is the most abundant thiol-containing molecule among low molecular mass thiols and plays key roles in the cellular control of ROS levels [24]. The ability of AKG to serve as a glutamate precursor for glutathione biosynthesis was shown earlier in human erythrocytes [25]. Therefore, we propose that in our experiments dietary AKG could be partially used for glutathione biosynthesis resulting in the increased L-SH levels in males. A main function of catalase is to scavenge hydrogen peroxide, one is the most abundant ROS. At the same time, when ROS levels are significantly increased, catalase can also undergo oxidative inactivation [24]. Thus, the lower catalase activity in AKG-fed flies could be due to the sensitivity of this enzyme to ROS attack, but it cannot be excluded that AKG could affect enzyme expression.

Is oxidative stress connected with longevity effects of $A K G$ ? Physiological effects of oxidative stress were proposed to depend on its intensity. Whereas strong oxidative stress has lethal effects and decreases longevity, the stress of low and intermediate intensity may have beneficial effects for organisms [24]. It is well-established that many low intensity stresses induce adaptive responses that can confer resistance to other strong stresses, delay behavioral aging and even prolong lifespan in $D$. melanogaster $[26,27]$. However, not all mild stresses demonstrated similar effects on the various traits analyzed [27]. In particular, low doses of hydrogen peroxide increased 
lifespan of $D$. melanogaster flies, but did not have positive effect on behavioral aging, resistance to heat or starvation [26]. In line with this, in our experiments, dietary AKG stimulated a degree of oxidative stress development but without positive effects on climbing activity, resistance to hydrogen peroxide or starvation in middle-aged flies, whereas it positively affected recovery from chill coma in flies of both genders and heat stress resistance in females. These data suggest that the AKG-mediated stress response may involve the induction of specific stressprotective mechanisms, and the induction of HSP synthesis can be among them. In particular, AKG has been shown recently to increase expression of HSP70 and HSP90 genes in fish liver [18], that supports our results.

Despite AKG induced oxidative stress in flies of both genders, lifespan extension was found only in AKG-fed females but not in males (Fig. 1, $A$ and $B)$. Therefore, we cannot definitely link oxidative stress to lifespan extension effects of AKG. It has been shown recently, that $D$. melanogaster flies lived longer on $10 \%$ carbohydrates than on $2 \%$ diets. Herewith, flies fed on $10 \%$ carbohydrates had higher levels of lipid peroxides and lower catalase activity than those fed $2 \%$ carbohydrates [28]. In our study, similar results were found for AKG-fed flies. The data indicate that the efficiency of antioxidant system and accumulation of oxidatively modified biomolecules are not tightly associated with aging and longevity of $D$. melanogaster.

This study demonstrates that AKG-supplemented food modulates lifespan of $D$. melanogaster in dose and gender-dependent manners. The lifespan-prolonging effects of the diet containing AKG were more expressed in Canton $\mathrm{S}$ female cohorts than in males. Collectively, the results suggest that the modulation of age-related metabolic changes rather than modulation of antioxidant defenses could underlie the lifespan-prolonging effects of AKG. Different effects of AKG on lifespan in female and male $D$. melanogaster indicate the importance of using both genders to study the role of the diets in processes related to lifespan, reproduction, and stress resistance. Furthermore, since we previously demonstrated a positive impact of AKG on climbing activity and oxidative stress resistance in another D. melanogaster line, the results of the present study suggest that effects of AKG on functional senescence in Drosophila can also be strain-specific and can depend on genetic background.
Acknowledgments. We are grateful to Bloomington Stock Center (Indiana University, USA) for providing the $D$. melanogaster strain, and students O. Humeniuk, V. Ivasyshyn, and N. Butenko for technical assistance. The work was partially supported by the Ministry of Education and Science of Ukraine (\#0115U002304) to VIL.

\section{ВПЛИВ АЛЬФА-КЕТОГЛУТАРАТУ НА ТРИВАЛІСТЬ ЖИТТЯ ТА ФУНКЦІОНАЛЬНЕ СТАРІННЯ Drosophila melanogaster}

\author{
М. П. Лилик', М. М. Байляк ${ }^{1}$, Г. В. Шмігель ${ }^{1}$, \\ Дж. М. Сторі ${ }^{2}$, К. Б. Сторі ${ }^{2}$, В. І. Лущак ${ }^{1}$
}

\author{
${ }^{1}$ Прикарпатський національний університет імені \\ Василя Стефаника, Івано-Франківськ, Україна; \\ ${ }^{2}$ Інститут біохімії, Карлетонський \\ університет, Оттава, Канада; \\ e-mail: lushchak@pu.if.ua; bayliak@ukr.net
}

Досліджено вплив альфа-кетоглутарату (АКГ) на тривалість життя та функціональне старіння Drosophila melanogaster лінії Canton S. Показано, що ефекти АКГ залежать від його концентрації та статі мух. Додавання до їжі 1-10 мМ АКГ не впливало на середню та максимальну тривалість життя самців, за винятком збільшення максимальної тривалості життя за 10 мМ АКГ. Водночас, АКГ (20 мМ) скорочував середню і не впливав на максимальну тривалість життя самців. У самок АКГ за концентрацій $1 \mathrm{i}$ 5 мМ не впливав на тривалість життя, а за вищих (10 та 20 мМ) - збільшував як середню, так і максимальну тривалість життя. За концентрації, яка збільшувала тривалість життя (10 мМ), АКГ знижував плодючість, підвищував стійкість до холодового стресу, проте не впливав на індуковану рухову активність та стійкість до окислювального стресу в мух обох статей середнього (24 дні) і старого (40 днів) віку. Дослідні самки середнього віку, але не самці, були стійкішими до теплового стресу та мали вищий вміст протеїну HSP90, ніж контрольні особини. Окрім того, мухи середнього віку на середовищі з АКГ мали вищі показники окислювального стресу, вищий вміст загального протеїну та триацилгліцеролів. Результати свідчать про те, що, передусім, модуляція вікових змін основного метаболізму, а не зниження інтенсивності оксидативного стресу, лежить в основі геропротекторної дії АКГ на D. melanogaster. 
К л ю ч о в і с ло в а: індукована рухова активність, плодючість, стійкість до стресів, окислювальний стрес, цикл трикарбонових кислот.

\section{ВЛИЯНИЕ АЛЬФА- КЕТОГЛУТАРАТА НА ПРОДОЛЖИТЕЛЬНОСТЬ ЖИЗНИ И ФУНКЦИОНАЛЬНОЕ СТАРЕНИЕ Drosophila melanogaster}

\author{
М. П. Лилик', М. М. Байляк ${ }^{1}$, Г. В. Шмигель ${ }^{1}$, \\ Дю. М. Стори ${ }^{2}$ К. Б. Стори ${ }^{2}$ В. И. Лущак ${ }^{1}$
}

\author{
${ }^{1}$ Прикарпатский национальный университет имени \\ Василия Стефаника, Ивано-Франковск, Украина; \\ ${ }^{2}$ Институт биохимии, Карлетонский \\ университет, Оттава, Канада; \\ е-мейл: lushchak@pu.if.ua; bayliak@ukr.net
}

Исследовано влияние альфа-кетоглутарата (АКГ) на продолжительность жизни и функциональное старение Drosophila melanogaster линии Canton S. Показано, что эффекты АКГ зависят от его концентрации и пола мух. Добавление к пище 1-10 мМ АКГ не влияло на продолжительность жизни самцов. В то же время, АКГ (20 мМ) сокращал среднюю и не влиял на максимальную продолжительность жизни самцов. У самок АКГ в концентрациях 1 и 5 мМ не влиял на продолжительность жизни, а при более высоких (10 и 20 мМ) - увеличивал среднюю и максимальную продолжительность жизни. При концентрации, которая увеличивала продолжительность жизни (10 мМ), АКГ снижал плодовитость, повышал устойчивость к холодовому стрессу, но не влиял на двигательную активность и устойчивость к окислительному стрессу у мух обоих полов среднего (24 дня) и старого (40 дней) возраста. Опытные самки среднего возраста, но не самцы, были более стойкими к тепловому стрессу и имели более высокое содержание протеина HSP90, чем контрольные особи. Кроме того, мухи среднего возраста на среде с АКГ имели высшие показатели окислительного стресса, содержание общего протеина и триацилглицеролов. Результаты свидетельствуют о том, что, скорее всего, модуляция возрастных изменений основного метаболизма, но не снижение интенсивности окислительного стресса, лежит в основе геропротекторного действия АКГ на D. melanogaster.
К л ю че в ы е с л о в а: индуцированная двигательная активность, плодовитость, устойчивость к стрессам, окислительный стресс, цикл трикарбоновых кислот.

\section{References}

1. Niemiec T, Sikorska J, Harrison A, Szmidt M, Sawosz E, Wirth-Dzieciolowska E, Wilczak J, Pierzynowski S. Alpha-ketoglutarate stabilizes redox homeostasis and improves arterial elasticity in aged mice. J Physiol Pharmacol. 2011; 62(1): 37-43.

2. Chin RM, Fu X, Pai MY, Vergnes L, Hwang $H$, Deng $G$, Diep S, Lomenick B, Meli VS, Monsalve GC, Hu E, Whelan SA, Wang JX, Jung G, Solis GM, Fazlollahi F, Kaweeteerawat C, Quach A, Nili M, Krall AS, Godwin HA, Chang HR, Faull KF, Guo F, Jiang M, Trauger SA, Saghatelian A, Braas D, Christofk HR, Clarke CF, Teitell MA, Petrascheck M, Reue K, Jung ME, Frand AR, Huang J. The metabolite $\alpha$-ketoglutarate extends lifespan by inhibiting ATP synthase and TOR. Nature. 2014; 510(7505): 397-401.

3. Zdzisińska B, Żurek A, Kandefer-Szerszeń M. Alpha-ketoglutarate as a molecule with pleiotropic activity: well-known and novel possibilities of therapeutic use. Arch Immunol Ther Exp (Warsz). 2017; 65(1): 21-36.

4. Bayliak MM, Lylyk MP, Sorochynska OM. Dietary alpha-ketoglutarate partially prevents age-related decline in locomotor activity and cold tolerance in Drosophila melanogaster. Biologia. 2017; 72(4): 458-467.

5. Bayliak MM, Lylyk MP, Shmihel HV, Sorochynska OM, Semchyshyn OI, Storey JM, Storey KB, Lushchak VI. Dietary alphaketoglutarate promotes higher protein and lower triacylglyceride levels and induces oxidative stress in larvae and young adults but not in middle-aged Drosophila melanogaster. Comp Biochem Physiol A Mol Integr Physiol. 2017; 204: 28-39.

6. Gospodaryov DV, Yurkevych IS, Lushchak OV, Lushchak VI. Correction: Lifespan extension and delay of age-related functional decline caused by Rhodiola rosea depends on dietary macronutrient balance. Longev Healthspan. 2013; 2(1): 12. 
7. Bayliak MM, Lylyk MP, Shmihel HV, Sorochynska OM, Manyukh OV, Pierzynowski SG, Lushchak VI. Dietary alphaketoglutarate increases cold tolerance in Drosophila melanogaster and enhances protein pool and antioxidant defense in sex-specific manner. J Therm Biol. 2016; 60: 1-11.

8. Lushchak OV, Gospodaryov DV, Rovenko BM, Glovyak AD, Yurkevych IS, Klyuba VP, Shcherbij MV, Lushchak VI. Balance between macronutrients affects life span and functional senescence in fruit fly Drosophila melanogaster. J Gerontol A Biol Sci Med Sci. 2012; 67(2): 118125.

9. Aebi H. Catalase in vitro. Methods Enzymol. 1984; 105: 121-126.

10. Bradford MM. A rapid and sensitive method for the quantitation of microgram quantities of protein utilizing the principle of protein-dye binding. Anal Biochem. 1976; 72: 248-254.

11. Ellman GL. Tissue sulfhydryl groups. Arch Biochem Biophys. 1959; 82(1): 70-77.

12. Lushchak VI, Semchyshyn HM, Lushchak OV. The classic methods to measure oxidative damage: lipid peroxides, thiobarbituric-acid reactive substances, and protein carbonyls. In: Oxidative stress in aquatic ecosystems. Eds. D. Abele, Vázquez-Medina, T. Zenteno-Savín. John Wiley \& Sons, Ltd, Chichester, UK, 2012, pp. 420-431.

13. Bergman I, Loxley R. New spectrophotometric method for the determination of proline in tissue hydrolyzates. Anal Chem. 1970; 42(7): 702-706.

14. Lee YP, Takahashi T. An improved colorimetric determination of amino acids with the use of ninhydrin. Anal Biochem. 1966; 14(1): 71-77.

15. Jones MA, Grotewiel M. Drosophila as a model for age-related impairment in locomotor and other behaviors. Exp Gerontol. 2011; 46(5): 320325.

16. Niveditha S, Deepashree S, Ramesh SR, Shivanandappa T. Sex differences in oxidative stress resistance in relation to longevity in Drosophila melanogaster. J Comp Physiol B. 2017; 187(7): 899-909.

17. Duncan RF. Inhibition of Hsp90 function delays and impairs recovery from heat shock. FEBS J. 2005; 272(20): 5244-5256.

18. Wang L, Xu Q, Wang C, Li J, Chen D, Zhao Z, Luo L, Du X. Effects of dietary $\alpha$-ketoglutarate supplementation on the antioxidant defense system and HSP70 and HSP90 gene expression of hybrid sturgeon Acipenser schrenckii $q \times$ A. baerii $\hat{\sigma}$ exposed to ammonia-N stress. Aquac Res. 2017; 48(5): 2266-2277.

19. Djawdan M, Sugiyama TT, Schlaeger LK, Bradley TJ, Rose MR. Metabolic aspects of the trade-off between fecundity and longevity in Drosophila melanogaster. Physiol Zool. 1996; 69(5): 1176-1195.

20. Chen CP, Walker VK. Cold-shock and chilling tolerance in Drosophila. J Insect Physiol. 1994; 40(8): 661-669.

21. Ballard JW, Melvin RG, Simpson SJ. Starvation resistance is positively correlated with body lipid proportion in five wild caught Drosophila simulans populations. J Insect Physiol. 2008; 54(9): 1371-1376.

22. Hoffmann AA, Hallas R, Sinclair C, Mitrovski P. Levels of variation in stress resistance in Drosophila among strains, local populations, and geographic regions: patterns for desiccation, starvation, cold resistance, and associated traits. Evolution. 2001;55(8): 1621-1630.

23. Kurgaliuk NM, Goryn OV. Effect of sodium $\alpha$-ketoglutarate injected after the X-ray treatment on the respiration and oxidative phosphorylation of the liver's mitochondria. Fiziol Zh. 2000; 46(5): 63-70. (In Ukrainian).

24. Lushchak VI. Free radicals, reactive oxygen species, oxidative stress and its classification. Chem Biol Interact. 2014; 224: 164-175.

25. Whillier S, Garcia B, Chapman BE, Kuchel PW, Raftos JE. Glutamine and $\alpha$-ketoglutarate as glutamate sources for glutathione synthesis in human erythrocytes. FEBS J. 2011; 278(17): 3152-3163.

26. Le Bourg E. Hormetic effects on longevity of hydrogen peroxide in Drosophila melanogaster flies living on a poorly nutritious medium. Biogerontology. 2007; 8(3): 327-344.

27. Le Bourg E. Using Drosophila melanogaster to study the positive effects of mild stress on aging. Exp Gerontol. 201; 46(5): 345-348.

28. Lushchak OV, Gospodaryov DV, Yurkevych IS, Storey KB. Oxidized lipids did not reduce lifespan in the fruit fly, Drosophila melanogaster. Arch Insect Biochem Physiol. 2016; 91(1): 52-63.

Received 05.08.2018 